\title{
Virus PCR Assay Panels: An Alternative to the Mouse Antibody Production Test
}

Walter A. Blank, PhD, Kenneth S. Henderson, PhD, and Lisa A. White, $\mathrm{PhD}$

\section{Antibody production tests have tra-} ditionally been used to test biological materials for viral contamination. Now molecular biology techniques have emerged as an alternative. The authors compare MAP testing with PCR-based detection methods, focusing on differences in animal use, laboratory requirements, sample size, and limits of detection.

The authors are affiliated with Charles River Laboratories, 251 Ballardvale Street, Wilmington MA 01887. Please address correspondence to White at Iwhite@criver.com.
The transmission of viruses through biological materials is of great concern to many researchers and managers of lab animal facilities. There is ample documentation ${ }^{1}$ for the confounding effects of such transmission on research of viral infections in experimental animals (often in the absence of clinical disease). Of even greater concern, outbreaks of infection among laboratory workers by zoonotic agents such as lymphotrophic choriomeningitis virus (LCMV) ${ }^{2}$ and hantavirus $^{3}$ are traceable to contaminated biological materials transplanted into animals. The biosecurity tenets of many research organizations require screening for viral agents of all cell lines, tumors, sera, and other biologicals before implantation or inoculation into animal models. Federal guidelines $^{4,5}$ also dictate that monoclonal antibodies (mAbs) and other biotechnology products derived from tissues or cell lines of animal origin are demonstrated to be free of viral contamination before their use for therapeutic or diagnostic purposes.
Until recently, the mouse antibody production (MAP) test was the primary method of screening for viruses of murine origin $^{6}$ (Table 1), but the application of modern molecular biology methods to this purpose presents certain advantages. In this article, we compare MAP testing with the polymerase chain reaction (PCR) for the detection of viral agents. Although our discussion concentrates on MAP testing in particular, the concepts presented in this paper are also applicable to rat and hamster antibody production (RAP and HAP) tests.

\section{MAP Testing Overview}

Rowe et al. ${ }^{7}$ first developed MAP testing as a simple and equally sensitive alternative to tissue culture for the detection of polyoma virus, and others have since applied it to simplify the detection of other agents ${ }^{8-12}$. Typical testing involves inoculating mice by multiple routes with a test article and holding them in isolation for a minimum of four weeks ${ }^{6}$. Researchers then collect serum

\section{TABLE 1. Mouse viruses screened for by MAP and PCR testing}

Agent

Mouse hepatitis virus (MHV)

Minute virus of mice (MVM)a

Mouse parvovirus (MPV)

Lactate dehydrogenase-elevating virus (LDV)

Lymphocytic choriomeningitis virus (LCMV) ${ }^{a}$

Mouse rotavirus (MRV, EDIM)a

Theiler's mouse encephalomyelitis virus (TMEV, GDVII)a

Ectromelia virus $^{a}$

Reovirus (type 1, type $3^{\text {a) }}$

Hantavirus (Hantaana, Seoul)

Polyoma virusa

Sendai virus ${ }^{a}$

Pneumovirus of mice (PVM)

$\mathrm{K}$ virus (pneumonitis virus) ${ }^{\mathrm{a}}$

Mouse cytomegalovirus (MCMV)a

Mouse thymic virus (MTV, MTLV)

Mouse adenovirus (MAV-1, MAV-2)

$\begin{array}{cc}\text { Virus group } & \text { Nucleic acid } \\ \text { Coronavirus } & \text { RNA } \\ \text { Parvovirus } & \text { DNA } \\ \text { Parvovirus } & \text { DNA } \\ \text { Togavirus } & \text { RNA } \\ \text { Arenavirus } & \text { RNA } \\ \text { Rotavirus } & \text { RNA } \\ \text { Picornavirus } & \text { RNA } \\ \text { Poxvirus } & \text { DNA } \\ \text { Reovirus } & \text { RNA } \\ \text { Bunyavirus } & \text { RNA } \\ \text { Papovavirus } & \text { DNA } \\ \text { Parainfluenzavirus } & \text { RNA } \\ \text { Paramyxovirus } & \text { RNA } \\ \text { Papovavirus } & \text { DNA } \\ \text { Herpesvirus } & \text { DNA } \\ \text { Herpesvirus } & \text { DNA } \\ \text { Adenovirus } & \text { DNA }\end{array}$

aFDA guidance recommends that MAP testing be performed for these agents on any master cell banks and end-of-production cells derived from murine cell lines and on all lots of mAbs derived from mouse ascites fluid ${ }^{4}$. 
samples from the animals and test them for virus-specific antibodies using the enzymelinked immunosorbent (ELISA), indirect fluorescent antibody (IFA), or hemagglutination inhibition (HAI) assays. Detection of virus-specific antibodies indicates the presence of that virus in the test article. The detection of lactate dehydrogenase-elevating virus (LDV), for which an effective antibody test does not exist, consists of screening serum for elevated levels of the enzyme lactate dehydrogenase.

The literature contains a number of surveys demonstrating the importance of MAP testing in the screening for viral agents (Table 2). LDV seems presently to be the most frequent contaminant, although reovirus, LCMV, minute virus of mice (MVM), and mouse hepatitis virus (MHV) are also detected regularly. The general trend during the last three decades seems to be toward fewer cases of contamination of the biological materials tested with the viral agents of interest. This decrease in prevalence coincides with a reduced rate of viral infections in animal colonies, a result of stricter biosecurity measures throughout the laboratory animal community-measures that include MAP testing of materials.

\section{Molecular Diagnostics: PCR- Based Testing}

Molecular biology methods permit the assaying of test articles directly for the presence of specific nucleic acids from contaminating infectious agents, as opposed to indirectly testing for the elicitation of an immune response. PCR is one of the most powerful and flexible of these molecular techniques, and in recent years it has been applied toward the replacement of MAP testing ${ }^{13-20}$.

The basic principle behind PCR is the in vitro amplification of a particular DNA sequence (e.g., a viral gene) in a sample to easily detectable levels, using a thermostable DNA polymerase enzyme (usually Taq polymerase), oligonucleotide primers specific for the target of interest, and a computer-controlled thermocycler that precisely manipulates the reaction temperatures ${ }^{21}$ (Fig. 1A). With each cycle of the PCR, newly synthe-

\section{TABLE 2. MAP test surveys for presence of viruses in biological materials}

\begin{tabular}{clrr}
$\begin{array}{c}\text { Year of study } \\
\text { (reference) }\end{array}$ & \multicolumn{1}{c}{$\begin{array}{c}\text { Biological material(s) } \\
\text { evaluated }\end{array}$} & $\begin{array}{c}\text { Number } \\
\text { tested }\end{array}$ & $\begin{array}{c}\text { Contamination } \\
\text { Rate (\%) }\end{array}$ \\
$1972(34)$ & Murine leukemia viruses, implantable tumors & 465 & 69 \\
$1987(6)$ & Tumor lines & 58 & 52 \\
& Hybridomas & 77 & 8 \\
& Tumors & 295 & 25 \\
& Cell lines & 109 & 4 \\
& mAb preparations or hybridomas & 600 & 2 \\
& Cell lines, tumors & 60 & 9
\end{tabular}

sized DNA molecules may act as templates for further amplification. The result of the process is an exponential increase in the number of target sequences, potentially creating billions of copies (also referred to as 'amplicons') from a single DNA template. Subsequent detection of the PCR products involves performing gel electrophoresis on an aliquot of the reaction mixture. After staining for visualization, the DNA molecules appear as discrete bands separated on the basis of their length, allowing for identification of the PCR product if the target sequence was present in the original sample.

Because PCR amplifies only DNA molecules, one detects viruses with RNA complementary sequences.
A

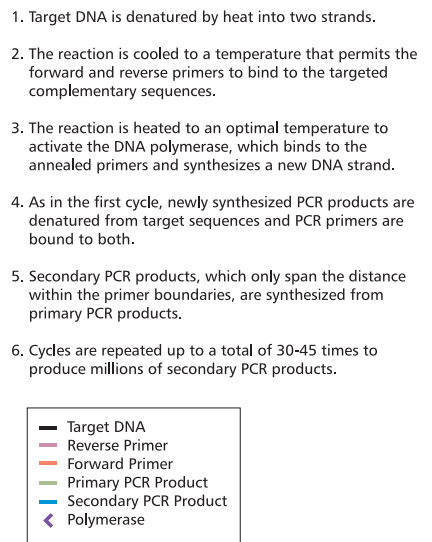

1. Target DNA is denatured by heat into two strand The reaction is cooled to a temperature that permits the

The reaction is heated to an optimal temperature to annealed primers and synthesizes a new DNA strand

As in the first cycle, newly synthesized PCR products are bound to both

Dendary PCR products, which only span the distance

of 30-45 times .

\section{PCR Amplification}

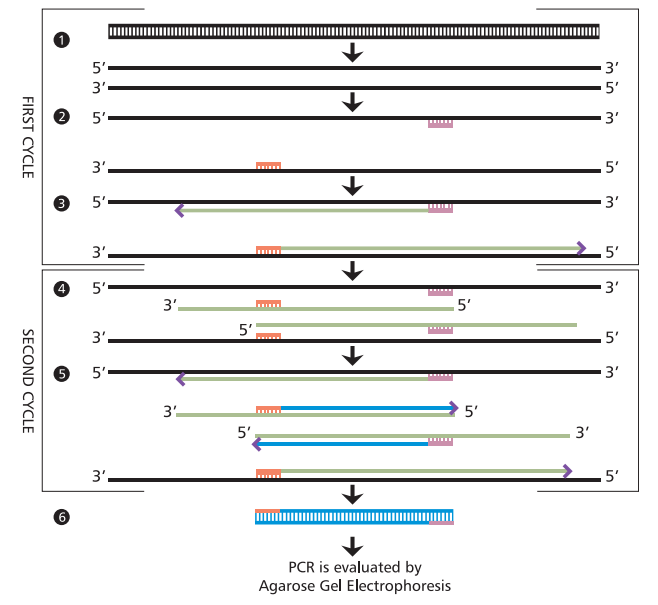

B

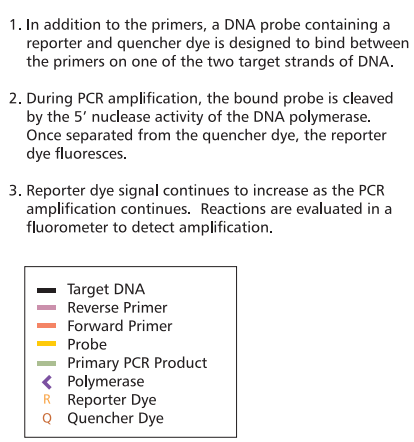

Fluorogenic 5' Nuclease PCR

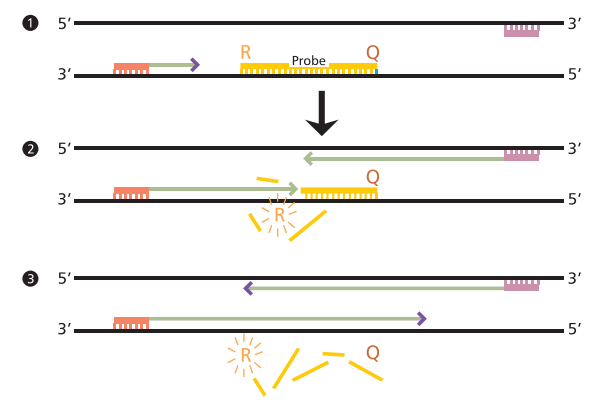

FIGURE 1. Molecular biology techniques, such as PCR (A) and fluorogenic 5'-nuclease PCR (B), can replace MAP testing by allowing the direct detection of nucleic acids from contaminating infectious agents. 


\section{TABLE 3. Commercial (US) providers of lab animal virus PCR panel} services

\section{Company name}

Charles River LaboratoriesLab Animal Diagnostic Services

Molecular Diagnostic Services, Inc.

University of Missouri Research Animal Diagnostic Laboratory
Location Wilmington, MA

San Diego, CA

Columbia, MO genomes (Table 1) by first performing a reverse-transcription (RT) reaction on the RNA test article, creating single-stranded complementary DNA (cDNA) molecules that are then used as template in the $\mathrm{PCR}^{22}$. RT-PCR can involve either a two-step reaction (generation of cDNA, then transfer of an aliquot to the PCR mixture) or a single step, in which the enzymes required for both reactions are present in the same tube.

Researchers have adapted numerous variations on the PCR method for the detection of infectious agents, all of which can be performed on DNA templates as well as on RNA templates after an RT step. A recent development that is particularly useful for diagnostic applications is the fluorogenic $5^{\prime}$-nuclease assay ${ }^{23}$, also known as TaqMan PCR, which makes use of an additional dye-labeled oligonucleotide probe that specifically hybridizes to the PCR product (Fig. 1B). As the amplification pro-

MAP Test

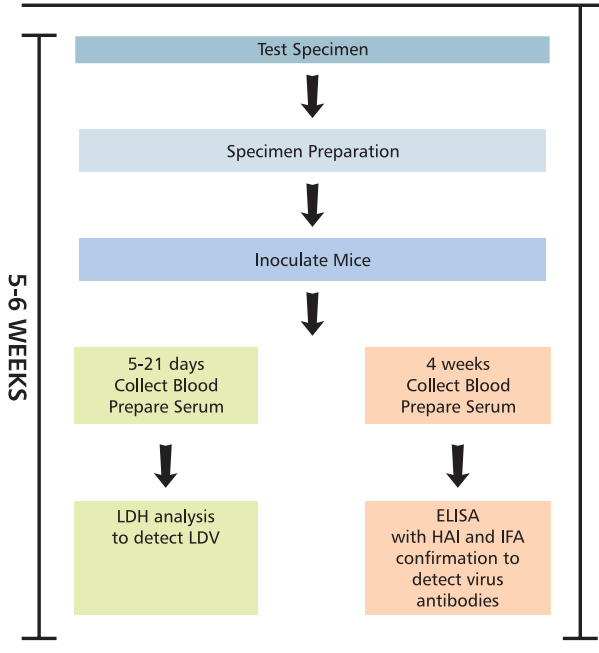

Virus Panel PCR

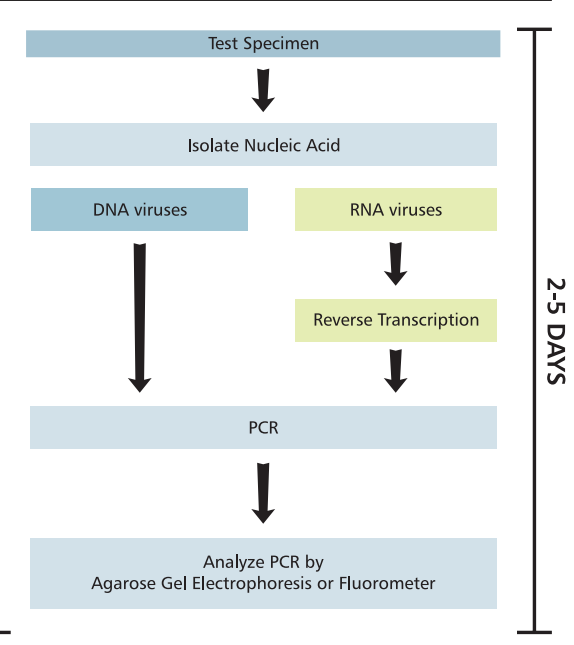

FIGURE 2. Among the advantages of the use of PCR rather than MAP testing is the substantial reduction in time needed to complete the test.
(Table 3). Costs will vary not only with providers but also depending on the number of agents of interest for testing. Generally, different panels of assays are available depending on customer needs. For instance, Charles River Laboratories (CRL) offers an "Essential" panel of 12 viruses and a "Comprehensive" panel of 18 viruses, although assays for individual viruses are also available. Virus PCR assay panels may also include testing for mycoplasmas, which are common bacterial contaminants of tumor and cell lines ${ }^{24,25}$.

\section{MAP versus PCR}

The steps involved in the MAP and PCR testing procedures appear in Figure 2. (Unless otherwise specified, comparisons between the procedures originate from protocols used at CRL.) MAP test sample preparation consists of homogenization, inactivation by osmotic lysis/freeze-thaw, and dilution as necessary before inoculation into the animals. Between 5 and 21 days after inoculation, technicians euthanize for serum collection the animals designated for LDV testing, and they collect serum for viral antibody testing from all other animals no sooner than 28 days after inoculation. For PCR, technicians extract the total nucleic acid (TNA; i.e., DNA and RNA) by chemical lysis of the test articles, followed by binding and washing on miniature columns containing silica resin, and elution from the columns. They can then use the aliquots of the purified TNA directly for PCR to detect DNA viruses, or they can subject them to RT before PCR for RNA viruses.

\section{Laboratory Requirements}

The animal facilities and trained personnel required for MAP testing are generally already present in organizations doing other types of animal experimentation. Because of the potential for infection, it is advisable to conduct MAP testing in facilities that are separate from areas used to house other animal studies. MAP testing requires immunocompetent mice free of antibodies against viral pathogens, and one must take additional precautions, such as using sterilized microisolation units and 
performing all animal manipulation in a biosafety cabinet, to avoid infection by viruses other than those potentially in the test articles and to prevent infection of other animals in the facility. Detection of antibodies (or enzyme levels, in the case of LDV) specific to the agents in question requires access to a serological testing laboratory.

PCR testing requires personnel trained in molecular biology techniques and specialized equipment, which includes still-air work hoods for sample processing, thermal cyclers, and gel electrophoresis equipment and/or fluorometric detection systems. To prevent false-positive results due to contamination with PCR templates, reagent preparation, sample processing, and PCR amplification/product detection should all take place in separate laboratories. Ideally, personnel should have laboratory-specific gowning and equipment, and workflow should proceed from 'clean' to 'dirty' areas to prevent the contamination of reagents and samples with amplicons generated in the amplification area.

\section{Time Required}

A primary advantage of using PCR panels is the reduction in the time between submission of the sample and reporting of results. MAP testing protocols require a minimum of 28 days after inoculation to allow the animals to mount a detectable immune response; specimen preparation and serological testing will contribute additional time to the total required for this method. By comparison, PCR allows the processing of test articles and analysis of results in a period as short as one to two days, although the number of samples being analyzed and resources available may increase turnaround time. Generally, PCR results become available in less than one week.

\section{Quantity of Test Article}

Standard MAP testing protocols call for a minimum of $3.5 \mathrm{ml}$ of test material, enough to inoculate five mice with $0.5 \mathrm{ml}$ intraperitoneally, $0.05 \mathrm{ml}$ intranasally, and $0.05 \mathrm{ml}$ orally, and to inoculate another five mice similarly with a 10 -fold dilution of the test material. One can dilute smaller amounts of

\section{TABLE 4. Comparison of MAP and PCR virus detection sensitivities}

\begin{tabular}{|c|c|c|c|c|c|}
\hline Agent & Reference & Units $^{a}$ & MAP test & $\begin{array}{c}\text { Gel-based } \\
\text { PCR }\end{array}$ & $\begin{array}{c}\text { Fluorogenic } \\
\text { PCR }\end{array}$ \\
\hline MAV & $\begin{array}{l}16 \\
\mathrm{CRL}\end{array}$ & $\begin{array}{l}\mathrm{TCID}_{50} \\
\mathrm{TCID}_{50}\end{array}$ & 0.1 & $3.2 \times 10^{-3}$ & $\begin{array}{r}3.2 \times 10^{-3} \\
3 \times 10^{-4}\end{array}$ \\
\hline MCMV & $\begin{array}{l}16 \\
\mathrm{CRL}\end{array}$ & $\begin{array}{l}\mathrm{TCID}_{50} \\
\mathrm{TCID}_{50}\end{array}$ & 15 & 15 & $\begin{array}{r}1.5 \\
4.6 \times 10^{-4}\end{array}$ \\
\hline Ectromelia & $\begin{array}{l}16 \\
\mathrm{CRL}\end{array}$ & $\begin{array}{l}\mathrm{TCID}_{50} \\
\mathrm{TCID}_{50}\end{array}$ & $3.2 \times 10^{-2}$ & $3.2 \times 10^{-3}$ & $\begin{array}{l}3.2 \times 10^{-3} \\
4.6 \times 10^{-3}\end{array}$ \\
\hline $\mathrm{K}$ virus & $\begin{array}{l}16 \\
\mathrm{CRL}\end{array}$ & $\begin{array}{l}\text { HA units } \\
\text { TCID }_{50}\end{array}$ & 1 & $1 \times 10^{-5}$ & $\begin{array}{r}1 \times 10^{-7} \\
1.4 \times 10^{-5}\end{array}$ \\
\hline MVM/MPV & $\begin{array}{l}16 \\
35 \\
36 \\
15 \\
\\
\text { CRL }\end{array}$ & $\begin{array}{l}\mathrm{TCID}_{50} \\
\mathrm{TCID}_{50} \\
\mathrm{TCID}_{50} \\
\mathrm{TCID}_{50} \\
\text { g DNA } \\
\text { TCID }_{50} \\
\text { Copies }\end{array}$ & $\begin{array}{r}1 \times 10^{2} \\
>1 \times 10^{-2}\end{array}$ & $\begin{array}{r}3.2 \\
1 \times 10^{-2} \\
1 \times 10^{-8}\end{array}$ & $\begin{array}{r}3.2 \times 10^{-3} \\
4.5 \times 10^{-4} \\
\\
1 \times 10^{-4} \\
1 \times 10^{-13} \\
1.2 \times 10^{-3} \\
<10\end{array}$ \\
\hline Polyoma & $\begin{array}{l}16 \\
\mathrm{CRL}\end{array}$ & $\begin{array}{l}\mathrm{TCID}_{50} \\
\mathrm{TCID}_{50}\end{array}$ & 0.32 & 0.32 & $\begin{array}{l}3.2 \times 10^{-5} \\
5.5 \times 10^{-4}\end{array}$ \\
\hline LDV & $\begin{array}{l}16 \\
\mathrm{CRL}\end{array}$ & $\begin{array}{l}I_{50} \\
I_{50} \\
\text { Copies }\end{array}$ & $1 \times 10^{2}$ & $1 \times 10^{-2}$ & $\begin{array}{r}1 \times 10^{-2} \\
0.2 \\
<10\end{array}$ \\
\hline MHV & $\begin{array}{l}16 \\
13 \\
14 \\
17 \\
\\
\text { CRL }\end{array}$ & $\begin{array}{l}\mathrm{TCID}_{50} \\
\mathrm{ID}_{50} \\
\text { Copies } \\
\text { TCID }_{50} \\
\text { g RNA } \\
\text { TCID }_{50} \\
\text { Copies }\end{array}$ & $\begin{array}{r}1 \times 10^{-3} \\
1 \times 10^{3} \\
2.5\end{array}$ & $\begin{array}{r}1 \times 10^{-3} \\
1 \times 10^{3} \\
1 \times 10^{3}\end{array}$ & $\begin{array}{r}1 \times 10^{-3} \\
\\
2.5 \\
2 \times 10^{-15} \\
3 \times 10^{-3} \\
<10\end{array}$ \\
\hline PVM & $\begin{array}{l}16 \\
19 \\
\text { CRL }\end{array}$ & $\begin{array}{l}\text { HA units } \\
\text { g RNA } \\
\text { TCID }_{50}\end{array}$ & $1 \times 10^{-2}$ & $1 \times 10^{-4}$ & $\begin{array}{r}1 \times 10^{-4} \\
1 \times 10^{-12} \\
5.5 \times 10^{-4}\end{array}$ \\
\hline Reo3 & $\begin{array}{l}16 \\
20 \\
\text { CRL }\end{array}$ & $\begin{array}{l}\operatorname{TCID}_{50} \\
\text { TCID }_{50} \\
\text { g RNA } \\
\text { TCID }_{50}\end{array}$ & $\begin{array}{r}10 \\
1\end{array}$ & 10 & $\begin{array}{r}1 \\
10 \\
<1 \times 10^{-15} \\
0.14\end{array}$ \\
\hline Sendai & $\begin{array}{l}16 \\
19 \\
\text { CRL }\end{array}$ & $\begin{array}{l}\mathrm{TCID}_{50} \\
\mathrm{TCID}_{50} \\
\text { g RNA } \\
\text { TCID }_{50}\end{array}$ & $\begin{array}{r}3.2 \\
80\end{array}$ & $3.2 \times 10^{-2}$ & $\begin{array}{r}3.2 \times 10^{-3} \\
80 \\
1 \times 10^{-14} \\
0.56\end{array}$ \\
\hline TMEV & $\begin{array}{l}16 \\
\mathrm{CRL}\end{array}$ & $\begin{array}{l}\mathrm{TCID}_{50} \\
\mathrm{TCID}_{50}\end{array}$ & 10 & 10 & $\begin{array}{r}1 \\
9 \times 10^{-2}\end{array}$ \\
\hline LCMV & $\begin{array}{l}16 \\
18 \\
\text { CRL }\end{array}$ & $\begin{array}{l}\text { PFU } \\
\text { TCID }_{50} \\
\text { g RNA } \\
\text { TCID }_{50}\end{array}$ & $\begin{array}{r}1 \\
6 \times 10^{-4}\end{array}$ & 1 & $\begin{array}{r}1 \\
6 \times 10^{-2} \\
1 \times 10^{-12} \\
1 \times 10^{-2}\end{array}$ \\
\hline EDIM & $\begin{array}{l}16 \\
\mathrm{CRL}\end{array}$ & $\begin{array}{l}\mathrm{TCID}_{50} \\
\mathrm{TCID}_{50}\end{array}$ & 32 & $3.2 \times 10^{-2}$ & $\begin{array}{r}3.2 \times 10^{-2} \\
0.12\end{array}$ \\
\hline MTLV & CRL & $\mathrm{TCID}_{50}$ & & & $1.2 \times 10^{-3}$ \\
\hline Hantaan & $\begin{array}{l}37 \\
\mathrm{CRL}\end{array}$ & $\begin{array}{l}\text { PFU } \\
\text { Copies }\end{array}$ & & 1 & $<10$ \\
\hline Seoul & $\begin{array}{l}38 \\
\mathrm{CRL}\end{array}$ & $\begin{array}{l}\text { FFU } \\
\text { Copies }\end{array}$ & & $7 \times 10^{-2}$ & $<10$ \\
\hline
\end{tabular}

${ }^{\mathrm{a}} \mathrm{TCID}_{50}, 50 \%$ tissue culture infectious dose; HA, hemagglutination units; g DNA or RNA, mass of nucleic acid; $I D_{50}, 50 \%$ animal infectious dose; copies, number of cloned or synthesized DNA template copies; PFU, plaque-forming units; FFU, focus-forming units. 
material before use, although this may diminish the sensitivity of the test. For researchers dealing with limited quantities of test article or very valuable samples, virus PCR panels may be the preferred method of testing. The assays performed at CRL require $5 \mu \mathrm{l}$ of extracted or reverse-transcribed DNA template per reaction; generally, $200 \mu$ l of test article is sufficient per panel, although we recommend the submission of duplicate samples to permit confirmatory testing. The binding capacity of the purification columns used in nucleic acid extractions will limit the number of cells or mass of tissue ( $\sim 10^{7}$ cells or $30 \mathrm{mg}$ of tissue) that may be processed at once for PCR testing.

\section{False Positives}

One of the most serious concerns with the use of PCR in a diagnostic capacity is that its high sensitivity makes it susceptible to false-positive results because of contaminating templates. Three potential sources of this contamination are other samples, experimental materials such as positive controls, and PCR products generated by previous reactions against the same target sequence $^{26}$. However, adequate precautions and controls can minimize contamination and detect it as such before erroneous results are reported.

The most effective method of contamination prevention is separation of tasks (reagent preparation; sample preparation; PCR amplification, and analysis) into different labs and maintenance of strict workflow procedures from 'clean' to 'dirty' areas. There must be no transfer between areas of room-designated equipment (pipettors, sample racks, etc.) and gowning. Personnel should only manipulate positive control templates in the amplification lab, and if possible, should prepare them in facilities separate from routine sample extraction. A quality control and tracking program for sample extraction and PCR reagents should also be in place. Assigning lot numbers when reagents are prepared and identification of aliquots in use can be very helpful in tracing the source of contamination in the event that it does occur, and personnel should use single-use aliquots whenever possible. To monitor contamination of reagents, personnel should always perform negative control reactions.

Strongly positive test articles present a potential source of contamination during sample preparation. During the processing steps, it is important to handle samples individually with no more than one tube open whenever possible. Still-air hood PCR workstations can help avoid transfer of aerosols between samples. A practice that we recommend is the submission of duplicate samples (e.g., two aliquots of the same test article) for PCR panel testing. Only one of the aliquots undergoes initial testing; in the event of a positive result, the untouched 'retain' sample undergoes extraction and retesting by the positive assay (including controls) to confirm the positive result.

Carryover contamination of PCR products from previous reactions is of particular concern, especially when analyzing PCR products on a gel; one can prevent it by a combination of including the enzyme uracil $\mathrm{N}$-glycosylase (UNG) and substituting the nucleotide deoxyuracil (dU) for thymine in PCR master mixes ${ }^{26}$. The alternate nucleotide becomes incorporated into all PCR products during the course of the reaction. In subsequent reactions, a brief incubation before PCR allows UNG to degrade any DNA molecules containing $\mathrm{dU}$ - that is, any products potentially carried over from earlier reactions-making them unavailable for amplification. 'Legitimate' templates containing thymine are unaffected, and the UNG is inactivated before PCR begins.

Serological assays may also give falsepositive results for numerous reasons, including incompletely purified antigens and cross-reactive antibodies ${ }^{27}$. Particular difficulties in the interpretation of MAP test results may arise if antibodies generated against the actual biological material being tested react with the cell culture control materials used in the preparation of ELISA antigens.

\section{False Negatives}

Although noninfectious virus particles can elicit an immune response, high anti- body titers are most likely to develop after active viral infections ${ }^{6}$, requiring the presence of adequate numbers of infectious viral particles for MAP testing to be successful. Many viruses can become noninfectious with changes in temperature or $\mathrm{pH}$, possibly resulting in inactivation during storage, transportation, or preparation of the test article. By contrast, PCR testing can detect infectious and noninfectious virus particles alike, provided that the sample has not been mishandled to such an extent that the nucleic acid has degraded.

PCR assays may be subject to inhibition by substances present in the test article that are not completely removed during the nucleic acid extraction procedure, leading to false-negative results. It is possible to detect inhibition by performing a separate 'spike' control assay in which limited copy numbers of another template are added along with the extracted sample to the PCR mixture. An independent assay evaluation of this assay with a positive result indicates the absence of PCR inhibitors.

Degradation of nucleic acids or inefficient recovery during extraction from test articles can also give false-negative results. One can control for this by adding another exogenous template in the early stages of sample preparation, then testing the final TNA extract for that template. This nucleic acid recovery control may also act as a spike control for PCR inhibitors, although separation of the two controls can simplify troubleshooting of a failed assay.

\section{Limits of Detection}

A summary of the published detection sensitivities of a number of PCR assays, along with some of our own sensitivity data, appears in Table 4. In a direct comparison of the PCR assays listed with MAP testing, 13 PCR assays were more sensitive than MAP testing and 5 were equally sensitive. The choice of animals used can influence the sensitivity of MAP testing itself, because some viruses elicit different levels of antibody response in particular mouse strains ${ }^{28,29}$. The limit of detection among PCR assays can vary greatly with the PCR technology, primer design, amplicon size, 
cycle parameters, PCR reagents, and nucleic acid extraction procedures. Furthermore, comparisons between different PCR assays for the same agent can be difficult to make when based on indirect virus titer methods such as infectivity assays. The sensitivity of these titering methods is highly dependent on a number of variables, including virus strain, host animal or cell line susceptibility, the ratio of infective to noninfective virus particles in the particular virus stock being tested, and culturing techniques.

For both MAP and PCR, assays that are very sensitive for known virus strains may not be capable of detecting divergent or newly emerging strains. Such was recently the case with a serological assay for MVM: the MVM ELISA did not detect the closely related mouse parvovirus (MPV) because of differences in their respective virus capsid proteins ${ }^{30}$. Similarly, PCR primers and probes must be targeted to genetic sequences that are highly conserved among all strains of the agent being tested. Agents with divergent sequences between strains or subspecies may require multiple (or degenerate) PCR primers or probes $^{31}$ within a reaction mixture, or may require additional assays. For instance, the absence of highly conserved sequences between hantaviruses led us to design separate assays for the Hantaan and Seoul strains.

\section{Regulatory Issues}

The widespread use of antibody production tests during the past decades has led to their broad acceptance as the method of choice to detect rodent viruses in biological materials to be used for studies following Good Laboratory Practices (GLP), as well as in products for human use such as biotechnology products derived from cell lines or mAbs. As such, FDA guidelines specifically mention antibody production tests ${ }^{4,5}$. One can also use other tests of at least equivalent sensitivity and reliability-including PCR tests - provided that adequate validation of each method is performed with respect to such aspects as sensitivity, selectivity (specificity), reproducibility, and stability ${ }^{32}$. Such validation experiments must take place on validated equipment with quality-controlled reagents using documented standard operating procedures. Appropriate documentation of all data and regular review by a Quality Assurance/Regulatory Affairs department are also necessary components of the process.

\section{Animal Use}

A distinct advantage of PCR panel testing is the replacement of animal-based testing with a series of in vitro assays, consistent with the 3 Rs of humane experimental technique (reduction, replacement, and refinement $)^{33}$. CRL's standard MAP testing procedure involves the inoculation of 10 mice with the test article and diluted test article, and another 4 mice with a negative control article. PCR use thus avoids the use of up to 14 animals per test article, along with any associated distress.

\section{Summary}

Screening of biological materials for infectious agents before use for in vivo experimentation is an important precaution for research integrity. Although the traditional method of accomplishing this has been serologically by the MAP test, the use of modern molecular biology techniques such as PCR permits such testing to be done much more rapidly with greater sensitivity and high reliability, provided that adequate controls are implemented.

\section{Received 9/23/02; accepted 11/17/03}

\section{References}

1. Committee on Infectious Diseases of Mice and Rats, Institute of Laboratory Animal Resources. Infectious Diseases of Mice and Rats 397 (National Academy Press, Washington, DC, 1991).

2. Hinman, A.R. et al. Outbreak of lymphocytic choriomeningitis virus infections in medical center personnel. Am. J. Epidemiol. 101(2), 103-110 (1975).

3. Lloyd, G. \& Jones, N. Infection of laboratory workers with hantavirus acquired from immunocytomas propagated in laboratory rats. J. Infect. 12(2), 117-125 (1986).

4. Food and Drug Administration. Points to consider in the manufacture and testing of monoclonal antibody products for human use. FDA, Docket No. 94D-0259. (28 February 1997). http://www.fda.gov/ cber/gdlns/ptc_mab.pdf.
5. Food and Drug Administration. Notice. International Conference on Harmonization: guidance on viral safety evaluation of biotechnology products derived from cell lines of human or animal origin. Federal Register 63(185), 51074-51084 (24 September 1998).

6. Shek, W.R. in Commercial Production of Monoclonal Antibodies (ed. Seaver, S.S.) 3-16 (Marcel Dekker, New York, NY, 1987).

7. Rowe, W.P., Hartley, J.W., Estes, J.D. \& Huebner, R.J. Studies on mouse polyoma virus infection. I. Procedures for quantitation and detection of virus. J. Exp. Med. 109, 379-391 (1959).

8. Hartley, J.W. \& Rowe, W.P. A new mouse virus apparently related to the adenovirus group. Virology 11, 645-647 (1960).

9. Parker, J.C. \& Reynolds, R.K. Natural history of Sendai virus infection in mice. Am. J. Epidemiol. 88(1), 112-125 (1968).

10. Lewis, V.J. \& Clayton, D.M. An evaluation of the mouse antibody production test for detecting three murine viruses. Lab. Anim. Sci. 21(2), 203-205 (1971).

11. de Souza, M. \& Smith, A.L. Comparison of isolation in cell culture with conventional and modified mouse antibody production tests for detection of murine viruses. J. Clin. Microbiol. 27(1), 185-187 (1989).

12. Morse, S.S. Comparative sensitivity of infectivity assay and mouse antibody production (MAP) test for detection of mouse thymic virus (MTLV). J. Virol. Methods. 28(1), 15-23 (1990).

13. Homberger, F.R., Smith, A.L. \& Barthold, S.W. Detection of rodent coronaviruses in tissues and cell cultures by using polymerase chain reaction. J. Clin. Microbiol. 29(12), 2789-2793 (1991).

14. Kunita, S., Terada, E., Goto, K. \& Kagiyama, N. Sequence analysis and molecular detection of mouse hepatitis virus using the polymerase chain reaction. Lab. Anim. Sci. 42(6), 593-598 (1992).

15. Redig, A.J. \& Besselsen, D.G. Detection of rodent parvoviruses by use of fluorogenic nuclease polymerase chain reaction assays. Comp. Med. 51(4), 326-331 (2001).

16. Bootz, F., Sieber, I., Popovic, D., Tischhauser, M., \& Homberger, F.R Comparison of the sensitivity of in vivo antibody production tests with in vitro PCR-based methods to detect infectious contamination of biological materials. $L a b$. Anim. 37(4), 341-351 (2003).

17. Besselsen, D.G., Wagner, A.M. \& Loganbill, J.K. Detection of rodent coronaviruses by use of fluorogenic reverse transcriptasepolymerase chain reaction analysis. Comp. Med. 52(2), 111-116 (2002).

18. Besselsen, D.G., Wagner, A.M. \& Loganbill, J.K. Detection of lymphocytic choriomeningitis virus by use of fluorogenic nuclease reverse transcriptase-polymerase chain reaction analysis. Comp. Med. 53(1), 65-69 (2003).

19. Wagner, A.M., Loganbill, J.K. \& Besselsen, D.G. Detection of Sendai virus and pneumonia virus of mice by use of fluorogenic nuclease reverse transcriptase polymerase chain reaction analysis. Comp. Med. 53(2), 173-177 (2003). 
20. Uchiyama, A., \& Besselsen, D.G. Detection of Reovirus type 3 by use of fluorogenic nuclease reverse transcriptase polymerase chain reaction. Lab. Anim. 37(4), 352-359 (2003).

21. Kendall, L.V. \& Riley, L.K. The Polymerase Chain Reaction (PCR). Contemp. Top. Lab. Anim. Sci. 38(6), 50 (1999).

22. Kendall, L.V. \& Riley, L.K. Reverse transcriptase polymerase chain reaction (RT-PCR). Contemp. Top. Lab. Anim. Sci. 39(1), 42 (2000).

23. Kendall, L.V., Besselsen, D.G. \& Riley, L.K. Fluorogenic 5'-nuclease PCR (real-time PCR). Contemp. Top. Lab. Anim. Sci. 39(5), 41 (2000).

24. Nicklas, W., Kraft, V. \& Meyer, B. Contamination of transplantable tumors, cell lines, and monoclonal antibodies with rodent viruses. Lab. Anim. Sci. 43(4), 296-300 (1993).

25. Nakai, N. et al. Detection and elimination of contaminating microorganisms in transplantable tumors and cell lines. Exp. Anim. 49(4), 309-313 (2000)

26. Hartley, J.L. \& Rashchian, A. in PCR Primer: A Laboratory Manual (eds. Dieffenbach, C.W. \& Dveksler, G.S.) 23-29 (Cold Spring Harbor Laboratory Press, Plainview, NY, 1995).
27. Weisbroth, S.H., Peters, R., Riley, L.K. \& Shek, W. Microbiological assessment of laboratory rats and mice. ILAR J. 39(4), 272-290 (1998)

28. Kagiyama, N., Takakura, A., Koyama, K., Terada, E. \& Sakurai, Y. Detection of mouse hepatitis virus antibody by protein A-ELISA in 6 prevalent inbred strains or outbred stocks of mice. Lab. Anim. 25(2), 106-109 (1991).

29. Besselsen, D.G., Wagner, A.M. \& Loganbill, J.K. Effect of mouse strain and age on detection of mouse parvovirus 1 by use of serologic testing and polymerase chain reaction analysis. Comp. Med. 50(5), 498-502 (2000).

30. Ball-Goodrich, L.J. \& Johnson, E. Molecular characterization of a newly recognized mouse parvovirus. J. Virol. 68(10), 6476-6486 (1994).

31. Gardner, S.N., Kuczmarski, T.A., Vitalis, E.A. \& Slezak, T.R. Limitations of TaqMan PCR for detecting divergent viral pathogens illustrated by hepatitis $A, B, C$, and $E$ viruses and human immunodeficiency virus. J. Clin. Microbiol. 41(6), 2417-2427 (2003).

32. Food and Drug Administration. Guidance for Industry: Bioanalytical Method Validation (2001). http://www.fda.gov/cder/guidance/4252fnl.htm.
33. Russell, W.M.S. \& Burch, R.L. The Principles of Humane Experimental Technique (Methuen \& Co., London, 1959). http://altweb.jhsph.edu/publications/humane_ exp/het-toc.htm.

34. Collins, M.J. Jr. \& Parker, J.C. Murine virus contaminants of leukemia viruses and transplantable tumors. J. Natl. Cancer Inst. 49(4), 1139-1143 (1972).

35. Zhan, D. et al. Detection of minute virus of mice using real-time quantitative PCR in assessment of virus clearance during the purification of mammalian cell substrate derived biotherapeutics. Biologicals. 30(4), 259-270 (2002).

36. Yagami, K., Goto, Y., Ishida, J., Ueno, Y., Kajiwara, N. \& Sugiyama, F. Polymerase chain reaction for detection of rodent parvoviral contamination in cell lines and transplantable tumors. Lab. Anim Sci. 45(3), 326-328 (1995).

37. Chu, Y.K., Jennings, G.B. \& Schmaljohn, C.S. A vaccinia virus-vectored Hantaan virus vaccine protects hamsters from challenge with Hantaan and Seoul viruses but not Puumala virus. J. Virol. 69(10), 6417-6423 (1995).

38. Kariwa, H. et al. Modes of Seoul virus infections: persistency in newborn rats and transiency in adult rats. Arch. Virol. 141(12), 2327-2338 (1996) 